\title{
Mathematical Modelling of Thin Layer Drying Kinetics of Amla-Beet Root Shreds
}

\author{
Mandali Pooja Rasagna* and S.K. Jain
}

Department of Processing and Food Engineering, College of Technology and Engineering, Udaipur 313 001, India

*Corresponding author

\section{A B S T R A C T}

\section{Keywords}

Drying models, Amla, Beet root, Tray dryer

Article Info

Accepted:

14 December 2017

Available Online:

10 January 2018
Drying kinetics of amla- beet root shreds in tray dryer was studied at 55, 65 and $75^{\circ} \mathrm{C}$ air temperatures. Drying of shreds occurred completely in falling rate period. Four thin layer drying models were fitted to the experimental moisture ratio data. Among the mathematical models investigated, the logarithmic model satisfactorily described the drying behaviour of shreds with high $\mathrm{r}^{2}$ values.

\section{Introduction}

Indian gooseberry (Emblica officinalis Gaertn.) also known as aonla is a low cost important fruit valued for its nutritional and medicinal properties. It is one of the richest sources of ascorbic acid (500-1,500 mg/100 g) used as a strong rejuvenator in Indian pharmacopoea (Pathak and Ram, 2007) and is very popular for its medicinal properties as mentioned both in ayurvedic and unani system of medicines in India. It is valued as an antiascorbic, acidic, cooling laxative and diuretic (Singh et al., 1993). Beetroot (Beta vulgaris L.) commonly known as 'chukander', is mainly cultivated in India for its juice and vegetable value. Beetroot is a rich source of potent antioxidants and nutrients, including magnesium, sodium, potassium and vitamin $\mathrm{C}$, and betaine. They are loaded with vitamins $A$, $\mathrm{B}_{1}, \mathrm{~B}_{2}, \mathrm{~B}_{6}$ and $\mathrm{C}$. They are also an excellent source of calcium, magnesium, copper, phosphorus, sodium and iron.

Traditionally fruits and vegetables are dried in open sunlight, which is weather dependable and also prone to microbial and other contamination (Mathioulakis et al., 1998). To achieve consistent quality dried product industrial dryers should be used. Industrial dryers are rapid and provide uniform, hygienic dried product (Abdelhaq and Labuza, 1987; Doymaz and Pala, 2002; Karathanos and Belessiotis, 1997). 
The drying kinetics of food is a complex phenomenon and requires simple representations to predict the drying behaviour, and for optimizing the drying parameters. Thin layer drying equations were used for drying time prediction for generalization of drying curves (Karathanos and Belessiotis, 1999). Extensive research in drying behaviour of pre-treated fruits was reported (Doymaz, 2004a, 2004b; Mahmutoglu et al., 1995; Saravacos et al., 1988; Verma and Gupta, 2004). But, no detailed studies were found in literature on drying kinetics of amla- beet root shreds. The objective of this study were (i) to study the drying kinetics of amla- beet root in a tray dryer and (ii) to evaluate a suitable thin layer drying model.

\section{Materials and Methods}

\section{Experiment}

Fresh matured Amla and beet root will be collected from local market, Udaipur. Fresh fruit samples will be washed and cut into small segments by using a manual shredder. Five different combinations of amla- beet root shreds were made on weight basis $\left[\mathrm{C}_{1}=(400\right.$, $0) ; C_{2}=(300,100) ; C_{3}=(200,200) ; C_{4}=(100$, $\left.0) ; \mathrm{C}_{5}=(0,100)\right]$.Each combination contained $400 \mathrm{~g}$ shreds. Each combination was blanched in one litre boiling water for $3 \mathrm{~min}$ and dipped immediately in normal water for 3 min to prevent excess cooking, then the blanched product was kept in strainer. Three percent (12 g) of black salt and 10 percent $(40 \mathrm{ml})$ ginger juice was given to each combination and kept for $12 \mathrm{~h}$ for uniform absorption (Prajapathi $e t$ al., 2010). The product was conditioned to remove surface moisture. Shreds were dried in tray dryer at three different temperatures (55 $\left.\left(\mathrm{T}_{1}\right), 65\left(\mathrm{~T}_{2}\right), 75\left(\mathrm{~T}_{3}\right){ }^{\circ} \mathrm{C}\right)$ in trays. The dryer was allowed to run for $30 \mathrm{~min}$ to reach the set drying air temperature conditions. Amla- beet root shreds were uniformly spread in rectangular aluminium trays and kept in the tray dryer for drying. Moisture loss was recorded at $30 \mathrm{~min}$ interval by a digital balance of $0.01 \mathrm{~g}$ accuracy. The drying was continued till there is no large variation in the moisture loss. Experiments were conducted in triplicate.

\section{Drying models}

Moisture ratio of samples during drying was expressed by the following equation:

Moistureratio $=\frac{M-M_{e}}{M_{0}-M_{e}}$

To select a suitable model for describing the drying process of amla- beet root shreds, drying curves were fitted with four thin layer drying equations. The moisture ratio models that are evaluated are presented in Table 1.The non-linear regression analysis was analysed using SPSS (Statistical Package for Social Science) 13.2 software package. Coefficient of correlation, $\mathrm{r}^{2}$ was one of the main criteria for selecting the best model. In addition to coefficient of correlation, the goodness of fit was determined by various statistical parameters such as mean bias error, MBE and root mean square error, RMSE. For quality fit, $\mathrm{r}^{2}$ value should be higher and MBE and RMSE values should be lower (Demir et al., 2004; Erenturk et al., 2004; Pangavhane et al., 1999; Sarsavadia et al., 1999; Togrul and Pehlivan, 2002).

\section{Results and Discussion}

\section{Drying characteristics}

The time taken for drying of amla- beet root shreds at different temperature is given in Table 2. The final moisture content of shreds ranged from $6 \%$ to $11 \%$ (d.b.). It is evident that the drying air temperature has an 
important effect on drying. When the temperature was increased, the drying time reduced. The results are similar with the earlier observations on drying of garlic slices (Madamba et al., 1996) and onion slices (Sarsavadia et al., 1999).

Curves of $\ln (\mathrm{MR})$ versus drying time for the samples dried at different temperature with different percentage of amla and beet root shreds are shown in Figs. 1-5. The moisture ratio decreased continuously with drying time.
An increase of drying rate was observed with the increase in temperature. Drying of amlabeet root shreds occurred in falling rate period and due to quick removal of moisture, no constant rate period was observed. Similar observations have been reported for the drying of red chillies (Chandy et al., 1992), onion slices (Rapusas and Driscoll, 1995) and apricots (Doymaz, 2004a). The drying in falling rate period shows that, internal mass transfer has occurred by diffusion.

Fig.1 Variation in $\ln (\mathrm{MR})$ with time for various drying airtemperatures for $\mathrm{C}_{1}$

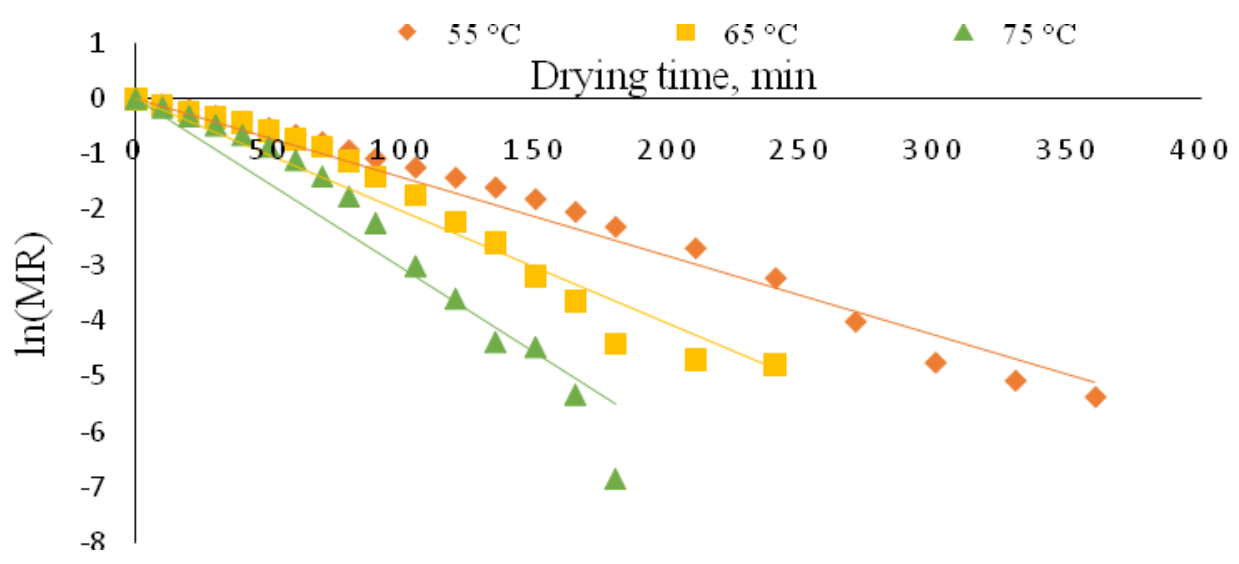

Fig.2 Variation in $\ln (\mathrm{MR})$ with time for various drying airtemperatures for $\mathrm{C}_{2}$

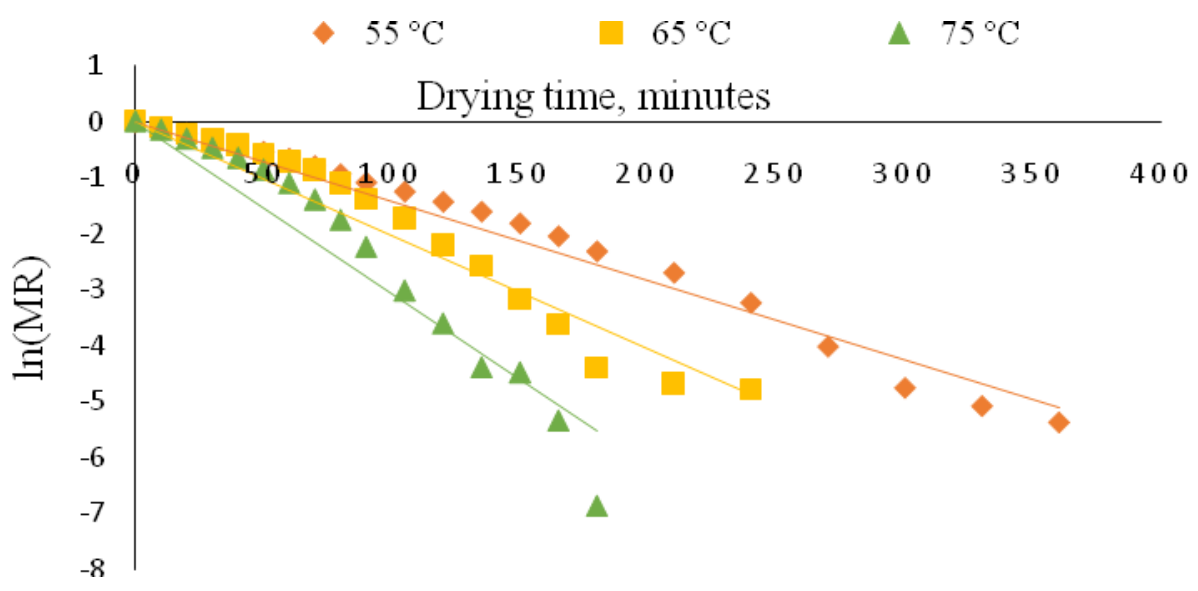


Fig.3 Variation in $\ln (\mathrm{MR})$ with time for various drying airtemperatures forC $\mathrm{C}_{3}$

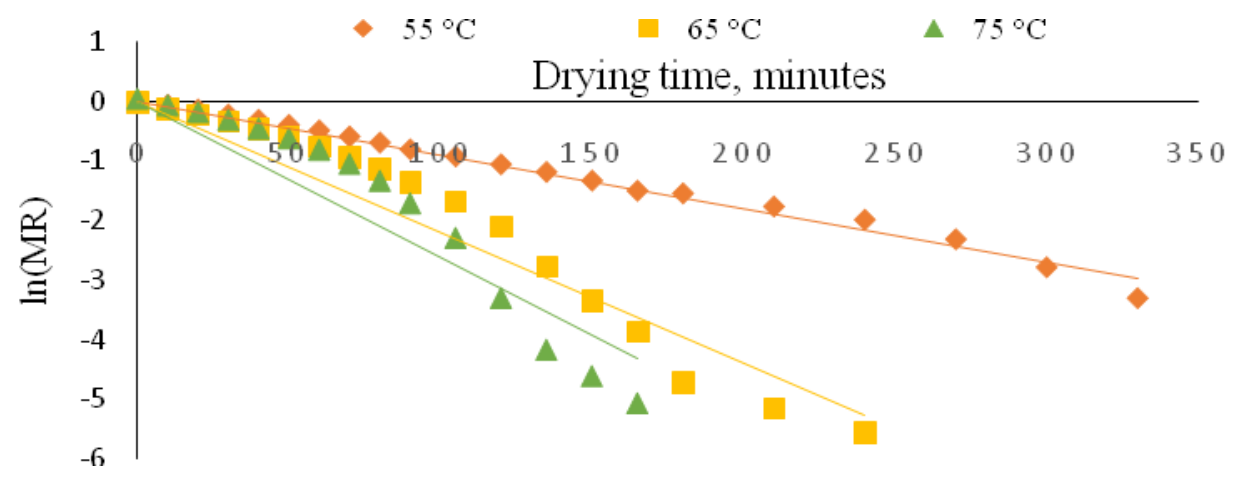

Fig.4 Variation in $\ln (\mathrm{MR})$ with time for various drying airtemperatures for $\mathrm{C}_{4}$

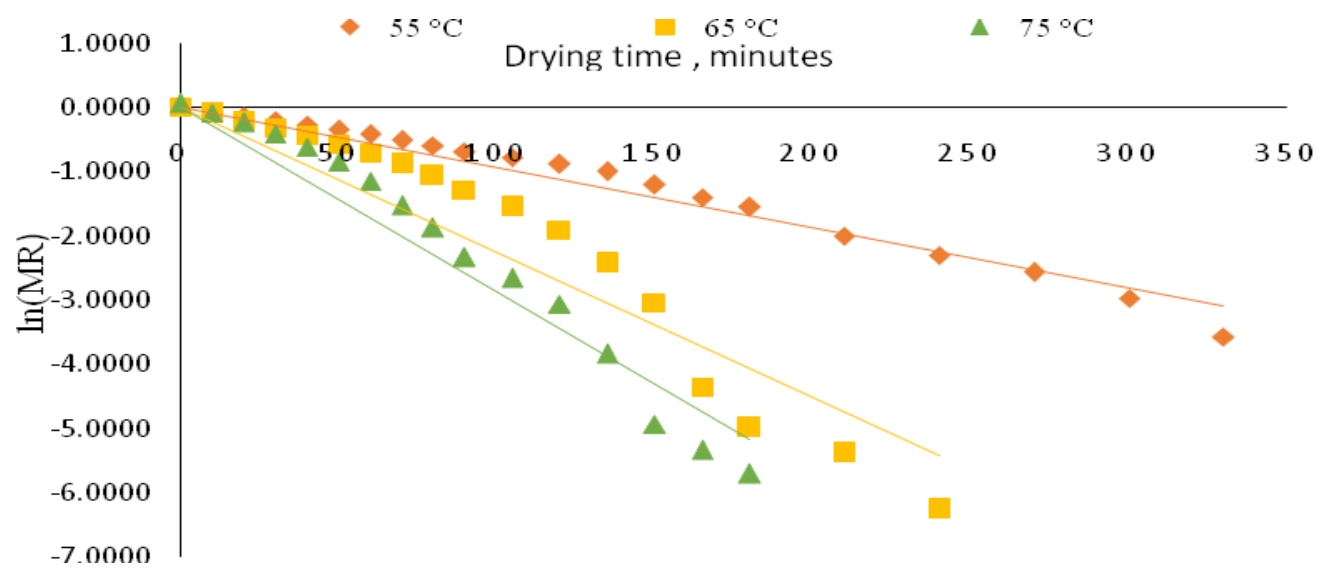

Fig.5 Variation in $\ln (\mathrm{MR})$ with time for various drying airtemperatures for $\mathrm{C}_{5}$

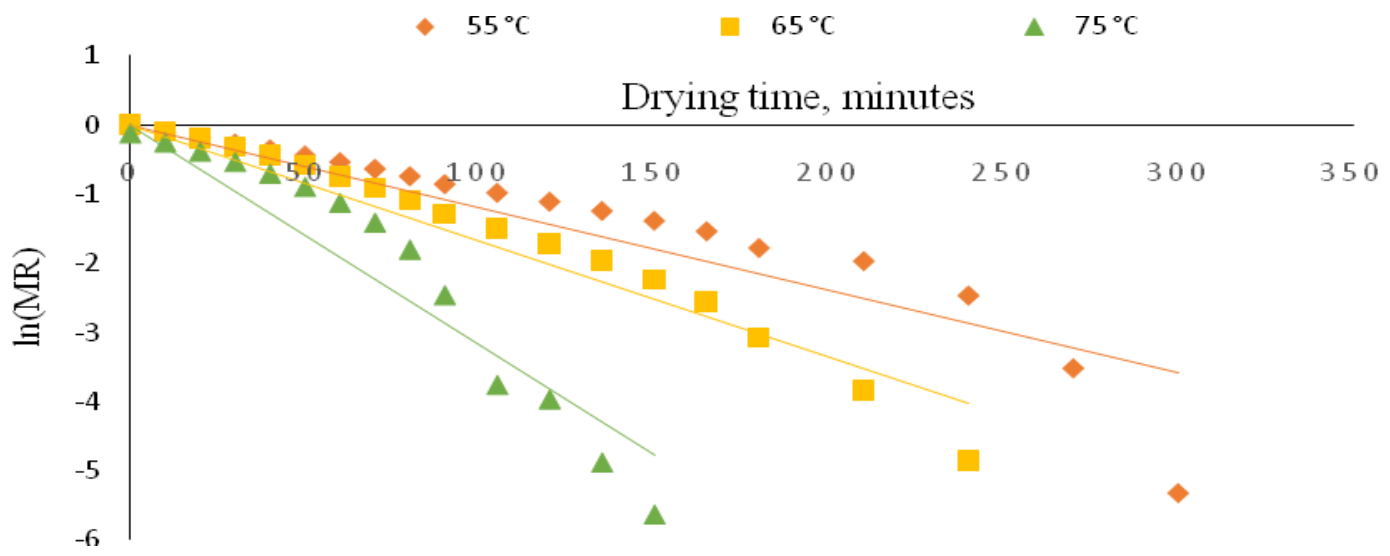


Table.1 Mathematical Models Used in Investigation

\begin{tabular}{|l|}
\hline Equation \\
\hline $\mathrm{MR}=\exp (\mathbf{k t})$ \\
\hline $\mathrm{MR}=\exp \left(\mathbf{k t} \mathbf{n}^{\mathbf{n}}\right)$ \\
\hline $\mathrm{MR}=\mathbf{a e x p}(\mathbf{k t})$ \\
\hline $\mathrm{MR}=\operatorname{aexp}(\mathbf{k t})+\mathrm{c}$ \\
\hline
\end{tabular}

\section{Name}

Newton

Page

Henderson and Pabis

Logarithmic

\section{References}

Liu and Bakker-Arkema (1997) and O'Callaghan et al., (1971)

Zhang and Litchfield (1991)

Henderson and Pabis (1961) and Chhinnman (1984)

Yaldiz et al., (2001)

Table.2 Drying time for amla- beet root shreds

\begin{tabular}{|c|c|c|c|}
\hline \multirow{2}{*}{ Sample } & \multicolumn{3}{|c|}{ Drying time (min) at different temperatures } \\
\hline $\mathrm{C}_{1}$ & $55^{\circ} \mathrm{C}$ & $65^{\circ} \mathrm{C}$ & $75^{\circ} \mathrm{C}$ \\
\hline $\mathrm{C}_{2}$ & 360 & 240 & 180 \\
\hline $\mathrm{C}_{3}$ & 360 & 300 & 180 \\
\hline $\mathrm{C}_{4}$ & 360 & 270 & 180 \\
\hline $\mathrm{C}_{5}$ & 360 & 270 & 180 \\
\hline
\end{tabular}

Table.3 Results on thin layer drying of $\mathrm{C}_{1}$ at different temperatures

\begin{tabular}{|c|c|c|c|c|c|c|c|c|}
\hline \multirow{2}{*}{$\begin{array}{l}\text { Name of } \\
\text { Model }\end{array}$} & \multirow{2}{*}{$\begin{array}{c}\text { Air Temp } \\
\left({ }^{\circ} \mathrm{C}\right)\end{array}$} & \multicolumn{4}{|c|}{ Drying constant } & \multicolumn{3}{|c|}{ Statistical parameters } \\
\hline & & $\mathbf{K}$ & n & $\mathbf{A}$ & c & MBE & $\mathbf{R}^{2}$ & RMSE \\
\hline \multirow{3}{*}{ 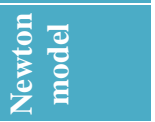 } & 55 & 0.012 & - & - & - & 0.0021 & 0.995 & 0.0268 \\
\hline & 65 & 0.013 & - & - & - & 0.0033 & 0.995 & 0.0288 \\
\hline & 75 & 0.019 & - & - & - & 0.0052 & 0.997 & 0.02156 \\
\hline \multirow{3}{*}{ 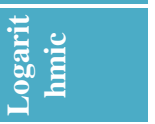 } & 55 & 0.011 & - & 1.101 & -0.072 & 0.0012 & 0.998 & 0.0161 \\
\hline & 65 & 0.011 & - & 1.100 & -0.085 & 0.0001 & 0.999 & 0.0103 \\
\hline & 75 & 0.016 & - & 1.029 & -0.048 & 0.0004 & 0.998 & 0.01545 \\
\hline \multirow{3}{*}{ 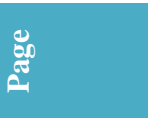 } & 55 & 0.984 & 0.000001 & - & - & 0.00000 & 0.969 & 0.20538 \\
\hline & 65 & 1.086 & 0.000001 & - & - & 0.00044 & 0.928 & 0.26738 \\
\hline & 75 & 1.268 & 0.000001 & - & - & 0.00084 & 0.901 & 0.23542 \\
\hline \multirow{3}{*}{ 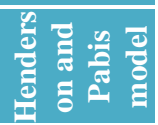 } & 55 & 0.012 & - & 1.048 & - & 0.00470 & 0.996 & 0.02376 \\
\hline & 65 & 0.014 & - & 1.039 & - & 0.00699 & 0.996 & 0.02531 \\
\hline & 75 & 0.019 & - & 0.997 & - & 0.00500 & 0.997 & 0.07074 \\
\hline
\end{tabular}

Table.4 Results on thin layer drying of $\mathrm{C}_{2}$ at different temperatures

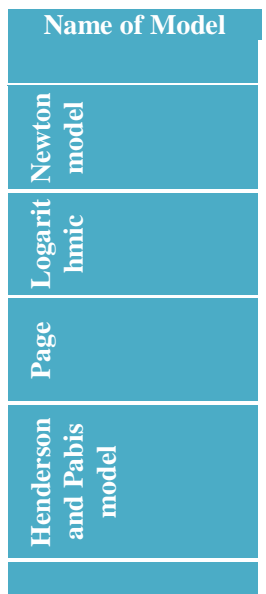

\begin{tabular}{|c|}
\hline $\begin{array}{c}\text { Air Temp } \\
\left({ }^{\circ} \mathrm{C}\right)\end{array}$ \\
\hline 55 \\
\hline 65 \\
\hline 75 \\
\hline 55 \\
\hline 65 \\
\hline 75 \\
\hline 55 \\
\hline 65 \\
\hline 75 \\
\hline 55 \\
\hline
\end{tabular}

\begin{tabular}{|c|c|}
\hline $\mathbf{k}$ \\
\hline 0.0116 \\
\hline 0.0142 \\
\hline 0.0196 \\
0.0110 \\
\hline 0.0130 \\
\hline 0.0166 \\
\hline 0.0070 \\
\hline 0.0028 \\
\hline 1.2933 \\
\hline 0.0119 \\
\hline
\end{tabular}

\begin{tabular}{|c|c|c|}
\hline Drying constant & A & C \\
\hline N & - & - \\
\hline- & - & - \\
\hline- & - & - \\
\hline- & 1.0454 & -0.03 \\
\hline- & 1.1187 & -0.06 \\
\hline- & 1.1324 & -0.09 \\
\hline- & - & - \\
\hline 1.11 & - & - \\
\hline 1.37 & - & - \\
\hline 0.000001 & 1.0251 & - \\
\hline- & & \\
\hline & & \\
\hline
\end{tabular}

\begin{tabular}{|c|c|c|}
\hline \multicolumn{3}{|c|}{ Statistical parameters } \\
\hline SSE & $\mathbf{R}^{2}$ & RMSE \\
\hline 0.0019 & 0.9982 & 0.01547 \\
\hline 0.0034 & 0.9742 & 0.04231 \\
\hline 0.0066 & 0.9883 & 0.04788 \\
\hline 0.0004 & 0.9993 & 0.01118 \\
\hline 0.0006 & 0.9991 & 0.02841 \\
\hline 0.0016 & 0.9997 & 0.02991 \\
\hline 0.0015 & 0.9997 & 0.00581 \\
\hline 0.0054 & 0.9977 & 0.02199 \\
\hline 0.0000 & 0.9417 & 0.27290 \\
\hline 0.0046 & 0.9986 & 0.0162 \\
\hline & & \\
\hline 0.0116 & 0.9896 & 0.04708 \\
\hline 0.012 & 0.985 & 0.0564 \\
\hline
\end{tabular}


Table.5 Results on thin layer drying of $\mathrm{C}_{3}$ at different temperatures

\begin{tabular}{|c|c|c|c|c|c|c|c|c|}
\hline \multirow{2}{*}{$\begin{array}{l}\text { Name of } \\
\text { Model }\end{array}$} & \multirow{2}{*}{$\begin{array}{l}\text { Air Temp } \\
\quad\left({ }^{\circ} \mathrm{C}\right)\end{array}$} & \multicolumn{4}{|c|}{ Drying constant } & \multicolumn{3}{|c|}{ Statistical parameters } \\
\hline & & $\mathbf{k}$ & $\mathbf{N}$ & $\mathbf{A}$ & c & SSE & $\mathbf{R}^{2}$ & RMSE \\
\hline \multirow{3}{*}{ 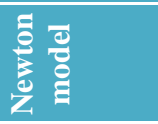 } & 55 & 0.0087 & - & - & - & 0.0018 & 0.9981 & 0.01518 \\
\hline & 65 & 0.0146 & - & - & - & 0.0045 & 0.988 & 0.0374 \\
\hline & 75 & 0.0079 & - & - & - & 0.0010 & 0.974 & 0.07823 \\
\hline \multirow{3}{*}{ 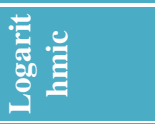 } & 55 & 0.0087 & - & 1.0397 & -0.01 & 0.0001 & 0.9993 & 0.0063 \\
\hline & 65 & 0.0126 & - & 1.1152 & -0.08 & 0.0005 & 0.9991 & 0.0049 \\
\hline & 75 & 0.0122 & - & 1.2869 & -0.20 & 0.0014 & 0.9994 & 0.0063 \\
\hline \multirow{3}{*}{$\begin{array}{l}\text { ED } \\
\text { E } \\
\approx\end{array}$} & 55 & 0.9270 & 0.000001 & - & - & 0.0009 & 0.9992 & 0.00997 \\
\hline & 65 & 1.2041 & 0.000001 & - & - & 0.0009 & 0.9725 & 0.28396 \\
\hline & 75 & 1.0886 & 0.000001 & - & - & 0.0023 & 0.9147 & 0.30540 \\
\hline \multirow{3}{*}{ 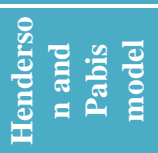 } & 55 & 0.0090 & - & 1.0296 & - & 0.0011 & 0.9992 & 0.01165 \\
\hline & 65 & 0.0154 & - & 1.0508 & - & 0.0121 & 0.9904 & 0.04452 \\
\hline & 75 & 0.0178 & - & 1.1301 & - & 0.0160 & 0.9838 & 0.06251 \\
\hline
\end{tabular}

Table.6 Results on thin layer drying of $\mathrm{C}_{4}$ at different temperatures

\begin{tabular}{|c|c|c|c|c|c|c|c|c|}
\hline \multirow{2}{*}{$\begin{array}{c}\text { Name of } \\
\text { Model }\end{array}$} & \multirow{2}{*}{$\begin{array}{c}\text { Air Temp } \\
\left({ }^{\circ} \mathrm{C}\right)\end{array}$} & \multicolumn{4}{|c|}{ Drying constant } & \multicolumn{3}{|c|}{ Statistical parameters } \\
\hline & & $\mathbf{k}$ & $\mathbf{N}$ & $\mathbf{A}$ & C & SSE & $\mathbf{R}^{2}$ & RMSE \\
\hline \multirow{3}{*}{ 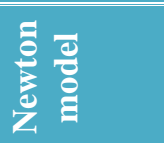 } & 55 & 0.0079 & - & - & - & 0.0007 & 0.9941 & 0.03362 \\
\hline & 65 & 0.0137 & - & - & - & 0.0043 & 0.9866 & 0.05419 \\
\hline & 75 & 0.0190 & - & - & - & 0.0007 & 0.9811 & 0.06716 \\
\hline \multirow{3}{*}{ 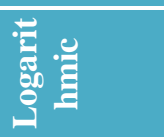 } & 55 & 0.0066 & - & 1.1340 & -0.11 & 0.0001 & 0.9991 & 0.01111 \\
\hline & 65 & 0.0120 & - & 1.1571 & -0.10 & 0.0001 & 0.9996 & 0.03095 \\
\hline & 75 & 0.0179 & - & 1.2036 & -0.08 & 0.0001 & 0.9995 & 0.02468 \\
\hline \multirow{3}{*}{ 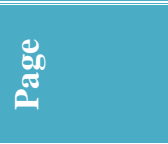 } & 55 & 0.8667 & 0.000001 & - & - & 0.0001 & 0.988 & 0.24226 \\
\hline & 65 & 1.1460 & 0.000001 & - & - & 0.0004 & 0.9672 & 0.23013 \\
\hline & 75 & 1.2516 & 0.000001 & - & - & 0.0041 & 0.9411 & 0.29259 \\
\hline \multirow{3}{*}{ 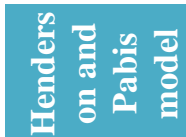 } & 55 & 0.0083 & - & 1.0476 & - & 0.0064 & 0.9959 & 0.02818 \\
\hline & 65 & 0.0149 & - & 1.0843 & - & 0.0126 & 0.9905 & 0.04557 \\
\hline & 75 & 0.0216 & - & 1.1430 & - & 0.0127 & 0.9910 & 0.04641 \\
\hline
\end{tabular}

Table.7 Results on thin layer drying of $\mathrm{C}_{5}$ at different temperatures

\begin{tabular}{|c|c|c|c|c|c|c|c|c|}
\hline \multirow{2}{*}{$\begin{array}{c}\text { Name of } \\
\text { Model }\end{array}$} & \multirow{2}{*}{$\begin{array}{c}\text { Air Temp } \\
\left({ }^{\circ} \mathrm{C}\right)\end{array}$} & \multicolumn{4}{|c|}{ Drying constant } & \multicolumn{3}{|c|}{ Statistical parameters } \\
\hline & & $\mathbf{K}$ & $\mathbf{N}$ & $\mathbf{a}$ & C & SSE & $\mathbf{R}^{2}$ & RMSE \\
\hline \multirow{3}{*}{ 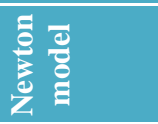 } & 55 & 0.0081 & - & - & - & 0.00266 & 0.9946 & 0.03267 \\
\hline & 65 & 0.0133 & - & - & - & 0.00089 & 0.9942 & 0.02663 \\
\hline & 75 & 0.0169 & - & - & - & 0.00628 & 0.9811 & 0.06449 \\
\hline \multirow{3}{*}{ 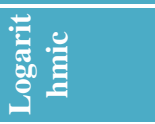 } & 55 & 0.0075 & - & 1.1185 & -0.07 & 0.00000 & 0.9994 & 0.00905 \\
\hline & 65 & 0.0123 & - & 1.1043 & -0.06 & 0.0027 & 0.9991 & 0.02119 \\
\hline & 75 & 0.0128 & - & 1.2176 & -0.17 & 0.0000 & 0.9994 & 0.03475 \\
\hline \multirow{3}{*}{$\begin{array}{l}\text { ED } \\
\text { ॠ } \\
\approx\end{array}$} & 55 & 0.8814 & 0.000001 & - & - & 0.02138 & 0.9084 & 0.07945 \\
\hline & 65 & 1.1088 & 0.000001 & - & - & 0.00032 & 0.9760 & 0.27186 \\
\hline & 75 & 1.1551 & 0.000001 & - & - & 0.00002 & 0.9465 & 0.29001 \\
\hline \multirow{3}{*}{ 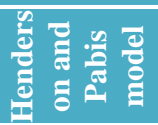 } & 55 & 0.0088 & - & 1.0676 & - & 0.00471 & 0.9979 & 0.02043 \\
\hline & 65 & 0.0142 & - & 1.0610 & - & 0.0069 & 0.9964 & 0.02659 \\
\hline & 75 & 0.0182 & - & 1.0824 & - & 0.01517 & 0.9851 & 0.05742 \\
\hline
\end{tabular}




\section{Models}

The moisture ratio data of shreds dried at different temperatures were fitted into the thin layer drying models (Table 1). The coefficient of correlation and results of statistical analyses are listed in Tables 3-7.In all cases, the $\mathrm{r}^{2}$ values for the mathematical models were greater than 0.90 , indicating a good fit. The results show that highest values of $r^{2}$ and lowest values of MBE and RMSE were obtained with the logarithmic model. Thus the logarithmic model may be assumed to represent the thin layer drying behaviour of amla- beet root shreds in tray dryer. Similar findings were reported for hot air drying of apricots (Doymaz, 2004a; Togrul and Pehlivan, 2002) and rosehip (Erenturk et al., 2004).

From this study on drying of amla- beet root shreds in a tray dryer, the following conclusions were drawn:

Increase in drying air temperature decreased the drying time.

Logarithmic thin layer drying equation represented the thin layer drying behaviour of amla- beet root shreds.

\section{Acknowledgement}

The authors are grateful to the Dean, College of Technology and Engineering, Udaipur for providing the necessary facilities for conducting the experiments.

\section{References}

Abdelhaq, E. H., and Labuza, T. P. 1987. Air drying characteristics of apricots. Journal of Food Science, 52(2), 342345.

Chandy, E., Ilyas, S. M., Samuel, D. V. K., and Singh, A. 1992. Effect of some physical treatments on drying characteristics of red chillies. In Proceedings of the international agricultural engineering conference, Bangkok, Thailand.

Demir, V., Gunhan, T., Yagcioglu, A. K., and Degirmencioglu, A. 2004. Mathematical modelling and the determination of some quality parameters of air-dried bay leaves. Biosystems Engineering, 88(3), 325-335.

Doymaz, I. 2004a. Effect of pre-treatments using potassium metabisulphite and alkaline ethyl oleate on the drying kinetics of apricots. Biosystems Engineering, 89(3), 281-287.

Doymaz, I. 2004b. Pretreatment effect on sundrying of mulberry fruits (Morus alba L.). Journal of Food Engineering, 65, 205-209.

Doymaz, I., and Pala, M. 2002. The effects of dipping pretreatments on air-drying rates of the seedless grapes. Journal of Food Engineering, 52, 413-417.

Erenturk, S., Gulaboglu, M. S., and Gultekin, S. 2004. The thin layer drying characteristics of rosehip. Biosystems Engineering, 89(2), 159-166.

Henderson, S. M., and Pabis, S. 1961. Grain drying theory I. Temperature effect on drying coefficient. Journal of Agricultural Engineering Research, 6(3), 169-174.

Karathanos, V. T., and Belessiotis, V. G. 1997. Sun and artificial air drying kinetics of some agricultural products. Journal of Food Engineering, 31, 35-46.

Karathanos, V. T., and Belessiotis, V. G. 1999. Application of thin-layer equation to drying data of fresh and semi-dried fruits. Journal of Agricultural Engineering Research, 74, 355-361.

Liu, Q., and Bakker-Arkema, F. W. 1997. Stochastic modelling of grain drying, part 2: Model development. Journal of Agricultural Engineering Research, 66, 
275-280.

Madamba, P. S., Driscoll, R. H., and Buckle, K. A. 1996. The thin layer drying characteristic of garlic slices. Journal of Food Engineering, 29, 75-97.

Mahmutoglu, T., Pala, M., and Unal, M. 1995. Mathematical modelling of moisture, volume and temperature changes during drying of pretreated apricots. Journal of Food Processing and Preservation, 19, 467-490. leather (pestil). Journal of Food Engineering, 54, 81-88.

Mathioulakis, E., Karathanos, V. T., and Belessiotis, V. G. 1998. Simulation of air movement in a dryer by computational fluid dynamics: Application for the drying of fruits. Journal of Food Engineering, 36, 183200.

O'Callaghan, J. R., Menzies, D. J., and Bailey, P. H. 1971. Digital simulation of agricultural dryer performance. Journal of Agricultural Engineering Research, 16, 223-244.

Pangavhane, D. R., Sawhney, R. L., and Sarsavadia, P. N. 1999. Effect of various dipping pre-treatment on drying kinetics of Thompson seedless grapes. Journal of Food Engineering, 39, 211216.

Pathak, R.K. and Ram, R.A. 2007. Organic production of aonla. In: National seminar on "Recent advances in production, protection and post-harvest management of grape, mandarin and arid fruits". College of Horticulture, Mandsaur, pp 133-136, March 17-18
Prajapati, V.K., Prabhat, K., Nema, Rathore, S.S. 2010. Effect of pretreatment and drying methods on quality of valueadded dried aonla (Emblica officinalis Gaertn) shreds. Journal of Food Science and Technology,48(1):45-52.

Rapusas, R. S., and Driscoll, R. H. 1995. The thin layer drying characteristics of white onion slices. Drying Technology, 13(89), 1905-1931.

Saravacos, G. D., Marousis, S. N., and Raouzeos, G. S. 1988. Effect of ethyl oleate on the rate of air-drying of foods. Journal of Food Engineering, 40, 219226.

Sarsavadia, P. N., Sawhney, R. L., Pangavhane, D. R., and Singh, S. P. 1999. Drying behaviour of brined onion slices. Journal of Food Engineering, 40, 219-226.

Singh I.S., Pathak R.K., Dwivedi R., Singh H.K., Aonla production and postharvest technology, N.D. Univ. Agric. Technol. Kumarganj, Tech. Bull., Faizabad, India, 1993.

Togrul, I. T., and Pehlivan, D. 2002. Mathematical modelling of solar drying of apricots in thin layers. Journal of Food Engineering, 55, 209-216.

Verma, R. C., and Gupta, A. 2004. Effect of pre-treatments on quality of solar-dried amla. Journal of Food Engineering, 65, 397-402.

Yaldiz, O., Ertekin, C., and Uzun, H. I. 2001. Mathematical modelling of thin layer solar drying of sultana grapes. Energy - An International Journal, 26, 457465.

\section{How to cite this article:}

Mandali Pooja Rasagna and Jain, S.K. 2018. Mathematical Modelling of Thin Layer Drying Kinetics of Amla-Beet Root Shreds. Int.J.Curr.Microbiol.App.Sci. 7(01): 1821-1828. doi: https://doi.org/10.20546/ijcmas.2018.701.221 